Ehrlich Ascites Tumor cells, while immune antisera for mouse erythrocytes and mouse liver homogenate have no haemolytic action. (3) The haemolytic action on sheep erythrocytes by immune antisera for Ehrlich Ascites Tumor cells does not appear to be due to a complete antigen in common between Ehrlich Ascites Tumor cells and sheep erythrocytes; the reaction in fact is not reversible, as immune antisera for sheep erythrocytes have not shown any toxic action in vitro for Ehrlich Ascites Tumor cells. (4) It may be stated that the haemolytic action for mouse, rat and sheep erythrocytes exercised by immune antisera for Ehrlich Ascites Tumor

\section{Nucleolar Localization of Succinic Dehydrogenase in Human Malignant Cells with MTT}

It is known that succinic dehydrogenase is absent in both nuclei and nucleoli of mammalian cells ${ }^{1-6}$, excepting in bird erythrocytes which according to BRACHET ${ }^{7}$ might be due to absence of mitochondria in these erythrocytes. Nucleolar localization of succinic dehydrogenase in normal and malignant stratified epithelia of human cervix were observed in this laboratory ${ }^{8}$ with $2,3,5$ triphenyl tetrazolium chloride (TrC) and 2,2'-di-p-nitrophenyl-5, 5'-diphenyl-3, 3'-(3,3'-dimethoxy-4, 4'-biphenylene) ditetrazolium chloride (Nitro-BT).

The present report is to confirm the nucleolar localization of succinic dehydrogenase with a third important tetrazolium salt, 3-(4,5-dimethyl-thiazolyl-2)-2,5-diphenyl tetrazolium bromide (MTT).

Frozen sections $(8 \mu)$ were cut from fresh unfixed epidermoid carcinomatous tissue of human cervix from two cases. The sections were mounted on clear glass slides and stained $^{9}$ in the incubating media containing MTT. The common controls to ensure the specificity of

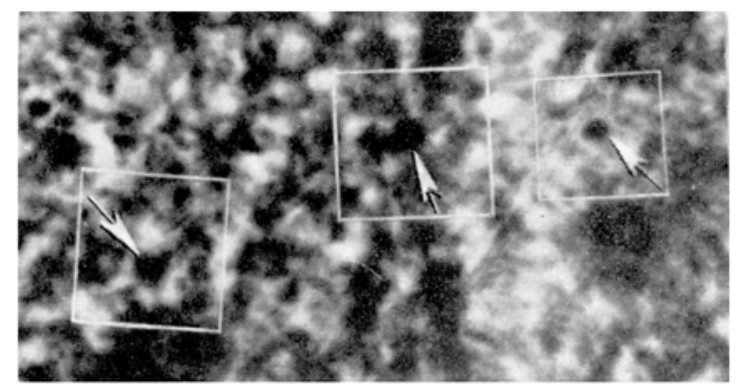

Frozen section of human epidermoid carcinoma cervix, stained for succinic dehydrogenase activity with MTT. Arrows exhibit nucleolar enzymatic activity in three malignant cells within the chelosed areas. (Objective $\times 10(1)$, eyepiece $12.5 \times$ ).

\section{Occurrence of an Eledoisin-Like Polypeptide (Physalaemin) in Skin Extracts of Physalaemus fuscumaculatus ${ }^{1}$}

Acetone and methanol extracts of wet or dry skin of Physalaemus fuscumaculatus, a South-American amphibian (Tucuman, Argentine), contain a principle which exerts a powerful stimulant action on several smoothmuscle preparations and potently lowers the systemic blood pressure in dogs and rabbits. cells might be due to the presence in the tumoral cells of an antigenic fraction of heterophile type.

Riassunto. Gli autori hanno osservato che i sieri di animali immunizzati con cellule del tumore cancro ascite di Ehrlich sono emolitici per gli eritrociti di topo, ratto e montone e presumono che le cellule del tumore di Ehrlich possano contenere frazioni antigene di tipo eterogenetico.

\section{A. ZinNari and V. Romiti}

Istituto di Patologia Generale dell'Università di Genova (Italy), June 20, 1962.

the reaction were applied ${ }^{410}$. An additional frozen section was stained by pyronin methylgreen for observing the position and size of the red stained nucleoli.

The sections were studied and photographed under oil immersion objective of a light microscope. More than one thousand cells were studied in each case.

Intracellular deposits of black cobalt formazan were observed in the cytoplasm and on the nucleolus-like intranuclear bodies of malignant cells. These stained intranuclear bodies exhibited (Figure) a morphological pattern of nucleoli. The body of the nuclei remained unstained.

Résumé. Les auteurs complètent leurs recherches sur la localisation cytochimique de l'activité de la déshydrogénase succinique dans les nucléoles en utilisant un troisième sel de tetrozolium, MTT d'une importance particulière.

\section{P. DE and R. Chatterjee}

Cell Research Departmeni, Chittaranjan National Cancer Reseavch Centre, Calcutta (India), August 13, 1962.

1. P. M. Marcause, Lab. Invest. 6, 137 (1957).

2 B. Monis, M. M. NaChlas, and A. II. Serigman, Cancer 12, 1238 (1958).

3 M. M. Nachlas, K. C. Tsov, İ. De Souza, C. S. Cheng, and A. M. SeligMan, J. Histochem. Cytochem. 5, 427 (1957).

4 K. OGAWA and H. M. ZTMMERMAN, J. Histochem. Cytochem. 7, 342 (1959).

5 B. PEARSON and V. DEFENDI, Cancer Res. 15,593 (1955)

6. W. Wachstein and L. Mersel, J. biophys. biochem. Cytol. 1,484 (1955).

7 J. Bracher, Biochemical Cytology (Acadenic Press Inc., New York $1957)$, p. 94.

8 P. De, R. Chatterjee, and S. Mitra, J. Histochem. Cytochem. 10, $6(1962)$.

9 A. G. E. PEARSE, Histochemistry, 2nd Ld. U. \& A. Chmrchill Ltd., London 1964 ), p. 910.

${ }^{10}$ R. FRIEDE, J. Histochem. Cytochem. 6, 350 (1958).

The active principle, which we call physalaemin, is in all probability a polypeptide. In fact, it was completely inactivated both by chymotrypsin and trypsin digestion (extract corresponding to $0.1 \mathrm{~g}$ fresh skin plus $100 \mu \mathrm{g}$ chymotrypsin or $1 \mathrm{mg}$ trypsin; incubation for $30 \mathrm{~min}$ at $\mathrm{pH} \quad 7.5-7.7$ and $38^{\circ} \mathrm{C}$ ), and acid hydrolysis of active chromatographic spots yielded a mixture of amino acids.

1 Supported by grants from the Consiglio Nazionale delle Ricerche, Roma, and the Rockefeller Foundation, New York. 